\title{
Study of the variability of the component composition of the essential oil of Artemisia vulgaris $L$. from the place of collection of raw materials in the territory of Dagestan
}

\author{
Fazina Vagabova ${ }^{1, *}$, and Aslan Aliev ${ }^{1,2}$ \\ ${ }^{1}$ Mountain Botanical Garden Dagestan Federal Research Centre of the Russian Academy of Sciences, \\ 367000, 75 Yaragskogo str., Makhachkala, Russian Federation \\ ${ }^{2}$ Kh. I. Amirkhanov Institute of Physics of the Dagestan Federal Research Centre of the Russian \\ Academy of Sciences, 367000, 93 Yaragskogo str., Makhachkala, Russian Federation
}

\begin{abstract}
The genus Artemisia L. is represented in the natural flora of Dagestan (Russia) by 21 species. For the first time, data are presented on the release of essential oil and its component composition in the aerial part of Artemisia vulgaris L., collected in different geographical points during the flowering period in 2014. The aim of the work was to assess the dependence of the accumulation and variability of the component composition of the essential oil of the aerial part of A. vulgaris on the place of collection of raw materials. The collected raw materials were dried to an air-dry state, ground in a laboratory mill and subjected to extraction by the Clevenger method (hydrodistillation method). The studied samples of wormwood showed a low content of essential oil, and one sample was colored dark blue, which differs from the literature data. The resulting essential oils were further analyzed on a gas chromatography-mass spectrometer (Shimadzu). As a result, 51 compounds were found in the essential oil of the aerial part of A. vulgaris (a sample collected in the vicinity of the village of Charoda, $1490 \mathrm{~m}$ above sea level, Dagestan, Russia), 56 compounds in a sample collected in the vicinity of the village of Kurush, $2460 \mathrm{~m}$ above sea level, Dagestan, Russia. Pinene beta, sabinene, myrcene, eucalyptol, terpinene gamma, thujone -beta, Verbenol trans, terpinen $-4-\mathrm{ol}$, chrysanthenyl acetate - trans, Isogermacrene D, muurolene epsylon, Humulene alpha, Cadinene gamma, Selyptol -Beta, Bulnesene alpha, Caryophyllene oxide, Humulene epoxide II, Chamazulene. Bulnesene alpha, Caryophyllene oxide, Humulene epoxide II, Chamazulene. Two samples of A. vulgaris essential oil differ in general both in qualitative and quantitative composition of components, both major and minor. The results obtained give us grounds to recommend these samples as sources of valuable components, chamazulene, Chrysanthenyl acetate, cubebene beta and others.
\end{abstract}

\footnotetext{
*Corresponding author: fazina@mail.ru
} 


\section{Introduction}

The genus Artemisia (family Asteraceae) is represented by about 500 species as grasses, shrubs and is distributed over the northern hemisphere from southern Asia, Europe, and North America. Medicinal and aromatic plants of this genus are important sources of secondary metabolites, especially essential oils [1-4]. Some types of wormwood are widely studied and used in the pharmaceutical industry. For example, it is known that essential oil, extracts of a number of species of the genus wormwood exhibit antimicrobial, antioxidant, cytotoxic, insecticidal, anti-inflammatory, antimutagenic, miscellaneous, repellent and anticonvulsant activities [1-15].

Common wormwood (Artemisia vulgaris L.) (common mugwort) is a perennial herbaceous medicinal plant with a height of $50 \mathrm{~cm}$ to $1.5 \mathrm{~m}$, which is distributed throughout the world. Grows in abandoned fields, along roads, water bodies. According to various sources, it blooms from July to September, the fruits ripen in August - October [16]. The chemical composition of the plant includes a large number of active compounds, namely: flavonoids, coumarins, vitamins, phenolic acids, alkaloids and essential oil, which makes it possible to expand the therapeutic activity of wormwood $[16,17]$. Currently, in Russia, the official type of raw material is dried wormwood herb as a sokogonny and appetiteincreasing agent [17].

The wormwood herb is used in cooking, in the cuisine of many nations as a spice, for cosmetic purposes, and in the textile industry (green paint). A. vulgaris essential oil is a colorless or pale yellow liquid with a strong bittersweet aroma and a hint of camphor. In medicine, essential oil, extracts of wormwood are used as a tonic, stimulating, healing, diuretic, soothing, hematopoietic, wound healing, choleretic, laxative, stimulating, anthelmintic, antioxidant, hepatoprotective, antispasmolytic, antrogenicanocicepotoxic effects, esthetic, insecticidal, antimicrobial, anti-parasitical, antipyretic, antiseptic, antihelmintic, tonica, diuretic activity [15-22].

The essential oil of representatives of the genus Artemisia contains major compounds characteristic of all types of wormwood, such as 1, 8-Cineole, beta-pinene, thujone, artemisia ketone, camphor, caryophyllene, camphene and germacrene D [1, 23]. The qualitative and quantitative composition of essential oils depends on various abiotic and biotic factors $[1,24,25]$.

Common wormwood is one of the most studied species of the genus wormwood. The greatest interest among researchers is the study of the biological activity of both the essential oil itself and its components, the variability of the composition of the essential oil depending on the geographical place of growth of this species, the height of the place of collection of raw materials above sea level, from the organ of the plant, the time of collection of raw materials, climatic conditions, soil composition [1, 11, 24-30]

According to the content of the main components of essential oil, four chemotypes of wormwood were distinguished [31]. Despite the large amount of data on the composition of the A. vulgaris essential oil growing in different geographic locations, work on the study of the chemical composition of the essential oil of the genus Artemisia and, in particular, wormwood in the flora of Dagestan is just beginning. The purpose of our work is to determine the dependence of the composition of A. vulgaris essential oil on the place of growth in the territory of Dagestan.

In our opinion, such works are important both for understanding the regularities of the biochemical reaction and, in practical terms, for identifying places of collection of $\mathrm{A}$. vulgaris in order to obtain a complete essential oil of a known composition and with a certain pharmacological effect. 


\section{Methods}

The genus Artemisia is represented in the natural flora of Dagestan by 21 species. Common wormwood is found in meadows, in shrubs, up to the upper mountain belt [32].

The aboveground part of the raw material for the production of essential oil was collected during the flowering period of 2014 in two geographical locations: env. with. Charoda, $1490 \mathrm{~m}$ above sea level sea and env. with. Kurush, $2460 \mathrm{~m}$ above sea level seas.

The collection of plant raw materials (aerial part of A. vulgare) to obtain essential oil was carried out at two geographic points at an altitude of $1490 \mathrm{~m}$ above sea level. sea (environs of the village of Charoda, Dagestan, Russia) and $2160 \mathrm{~m}$ above sea level. seas (the vicinity of the village of Kurush, the bed of the Mularchay river, Dagestan, Russia) in 2014 during the flowering period.

Sample preparation for the extraction of essential oils was carried out according to the standard procedures of the State Pharmacopoeia XI [33]. The plant raw material was preliminarily ground in a mill for plant samples MRP-12, then subjected to hydrodistillation to extract essential oils for 2-4 hours in an apparatus for extracting essential oils [33].

The content of the components was calculated from the areas of gas chromatographic peaks without using correction factors. The qualitative analysis is based on a comparison of the retention times of SupelcoSLBTM-5ms $(30 \mathrm{mx} 0.25 \mathrm{mmx} 0.25 \mu \mathrm{m})$ in split mode.

Helium of $99.9999 \%$ purity with a flow rate of $1 \mathrm{ml} / \mathrm{min}$ was used as a carrier gas. The column temperature was raised from $60^{\circ} \mathrm{C}$ (holding for $4 \mathrm{~min}$ ) to $150^{\circ} \mathrm{C}$ at a rate of $10^{\circ}$ $\mathrm{C} / \mathrm{min}$, then up to $250^{\circ} \mathrm{C}$ at a rate of $5^{\circ} \mathrm{C} / \mathrm{min}$. The injector, interface and detector temperatures were $250^{\circ} \mathrm{C}$. Ionization by electron impact with an electron energy of $70 \mathrm{eV}$. The emission current of the cathode is $60 \mu \mathrm{A}$, the range of registered ions is $\mathrm{m} / \mathrm{z} 45-500$, the scanning speed is $2500 \mathrm{~m} / \mathrm{z}$. Component identification was carried out using the NIST08 and FFNSC mass spectra libraries. Before analysis, the sample was diluted 1000 times in n-hexane. $1 \mu \mathrm{L}$ of the diluted sample was injected into the instrument with a flow split of 1:40 [34, 35].

Statistical processing of the data on the determination of essential oil yield indicators was carried out according to generally accepted data processing algorithms using the Statisticav licensed data processing system. 5.5. and software package "MS EXCEL".

\section{Results}

As a result of hydrodistillation from the aerial part of two A.vulgaris samples (Charodin and Kurush populations), the yield of essential oils was $0.1 \%$ and $0.18 \%$ of the air-dry mass of the raw material. At the same time, the essential oil of the Kurush population sample had a light yellow color, and the essential oil of the Charodin population sample was dark blue. The resulting essential oils were analyzed for their component composition by gas chromatography-mass spectrometry. The results obtained are shown in Fig. 1, 2 and in table 1. 


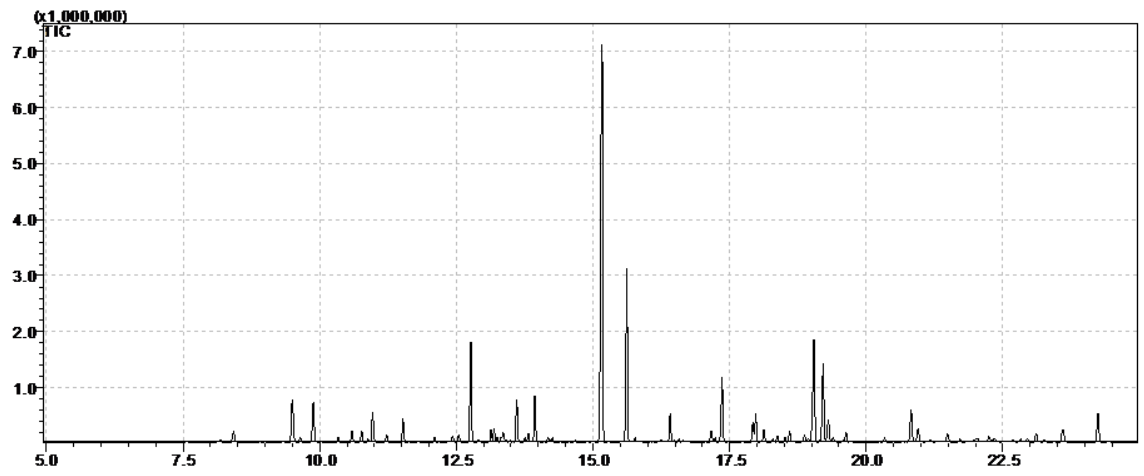

Fig. 1. Chromato-mass spectrogram of the essential oil of the aerial part of A.vulgaris L., the vicinity of the village of Kurush, Dagestan, Russia, collection 2014. Source: Compiled by the authors.

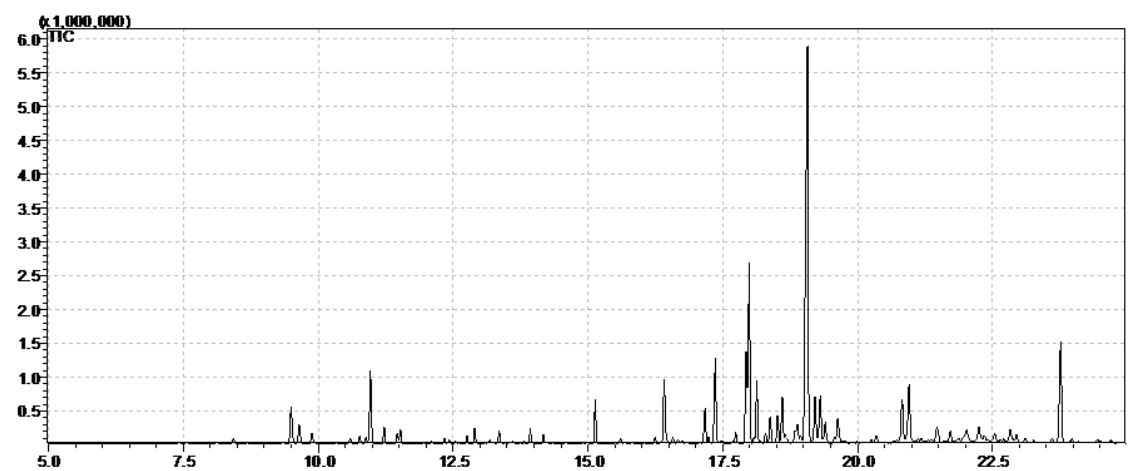

Fig. 2. Chromato-mass spectrogram of the essential oil of the aerial part of A.vulgaris L., the vicinity of the village of Charoda, Dagestan, Russia, collection 2014. Source: Compiled by the authors.

Table 1. Component composition of essential oil of the aerial part of Artemisia vulgaris L. from natural populations of Dagestan, Russia, collection of 2014.

\begin{tabular}{|c|l|c|c|}
\hline $\begin{array}{c}\text { № } \\
\mathbf{I} / \mathbf{I I}\end{array}$ & $\begin{array}{c}\text { Name of essential oil } \\
\text { compounds }\end{array}$ & $\begin{array}{c}\text { Environs of the } \\
\text { village of } \\
\text { Charoda, } \mathbf{h}= \\
\mathbf{1 4 9 0} \mathbf{m} \text { above sea } \\
\text { level. sea, } \\
\mathbf{0 7 . 0 7 . 2 0 1 4}\end{array}$ & $\begin{array}{c}\text { Environs of the village } \\
\text { of Kurush, bed of the } \\
\text { Mularchay river, } \mathbf{h}= \\
\mathbf{2 4 6 0} \mathbf{~ m} \text { above sea level. } \\
\text { sea, 08/11/2014 }\end{array}$ \\
\hline 1 & Thujene alpha & 0 & 0,13 \\
\hline 2 & pinene alpha & 0,33 & 0,89 \\
\hline 3 & Sabinene & 2,06 & 3,12 \\
\hline 4 & pinene beta & 1,04 & 0,38 \\
\hline 5 & myrcene & 0,55 & 2,61 \\
\hline 6 & Phellandrene alpha & 0 & 0,35 \\
\hline 7 & terpinene alpha & 0,27 & 0,76 \\
\hline 8 & cymene- para & 0,35 & 0,67 \\
\hline 9 & Limonene & 0,29 & 0,24 \\
\hline 10 & eucalyptol & 3,68 & 1,92 \\
\hline 11 & Ocimene beta-(E) & 0,74 & 0,45 \\
\hline 12 & Artemisia ketone & 0,44 & 0 \\
\hline
\end{tabular}




\begin{tabular}{|c|c|c|c|}
\hline 13 & Terpinene gamma & 0,61 & 1,34 \\
\hline 14 & terpinolene & 0,11 & 0,31 \\
\hline 15 & linalool & 0,26 & 0 \\
\hline 16 & nonanal & 0,15 & 0,39 \\
\hline 17 & 3-thujanone & 0 & 0,48 \\
\hline 18 & Thujone -beta & 0,38 & 5,58 \\
\hline 19 & Neothujol & 0 & 0,68 \\
\hline 20 & Miroxide $-(Z)$ & 0,64 & 0 \\
\hline 21 & Sabinol- trans & 0.14 & 0,69 \\
\hline 22 & Verbenol cis & 0 & 0,60 \\
\hline 23 & camphor & 0,54 & 0,57 \\
\hline 24 & Verbenol trans & 0 & 2,36 \\
\hline 25 & Alpha - phellandren-8-ol & 0 & 0,22 \\
\hline 26 & borneol & 0 & 0,39 \\
\hline 27 & menthol & 0 & 0,05 \\
\hline 28 & Terpinen -4 -ol & 0,62 & 2,38 \\
\hline 29 & Terpineol - alpha & 0,36 & 0,28 \\
\hline 30 & decanal & 0 & 0,21 \\
\hline 31 & $\begin{array}{l}\text { Chrysanthenyl acetate - } \\
\text { trans }\end{array}$ & 1,72 & 27,51 \\
\hline 32 & geranial & 0 & 0,08 \\
\hline 33 & Sabinyl-acetate trans & 0,18 & 9,23 \\
\hline 34 & Pinocaryl acetate trans & 0 & 0,21 \\
\hline 35 & $\begin{array}{l}\text { o-Ment-8-ene, } \\
\text { 4isopropylidene - 1-vinyl }\end{array}$ & 0,24 & 1,45 \\
\hline 36 & bicoclogermacrene & 5,75 & 1,48 \\
\hline 37 & Terpinyl acetate -alpha & 0,26 & 0,20 \\
\hline 38 & $\begin{array}{l}\text { 1,2,4-Metheno-1H- } \\
\text { indene,octahydro-1,7a- } \\
\text { dimethyl-5-(1- } \\
\text { methylethyl)-, [1S- } \\
\text { (1.alpha.,2.alpha.,3a.beta., } \\
\text { 4.alpha.,5.alpha.,7a.beta.. }\end{array}$ & 0 & 0,76 \\
\hline 39 & copaene & 1,75 & 0 \\
\hline 40 & Elemene -beta & 0,22 & 0,27 \\
\hline 41 & $\begin{array}{l}\text { Cyclohexane,1-ethenyk- } \\
\text { 1-methyl-2,4-bis(1- } \\
\text { methylethenyl)-, [1S- } \\
\text { (1.alpha.,2.beta.,4.beta.)] }\end{array}$ & 4,29 & 4,02 \\
\hline 42 & Bergamotene alpha, cis & 0,48 & 0 \\
\hline 43 & Cubebene beta & 34,74 & 1,93 \\
\hline 44 & Caryophyllene trans & 8,69 & 1,70 \\
\hline 45 & Bergamotene alpha, trans & 0,25 & 0 \\
\hline 46 & Farnezene -бета-trans & 0,44 & 0,22 \\
\hline 47 & Isogermacrene D & 1,33 & 0,43 \\
\hline 48 & Muurolene epsylon & 1,28 & 0,32 \\
\hline 49 & Humulene alpha & 1,98 & 0,60 \\
\hline 50 & Cadinene gamma & 0 & 6,90 \\
\hline 51 & Selynene betaH & 0 & 4,78 \\
\hline 52 & Curcumene gamma & 0,53 & 0 \\
\hline 53 & Not ident. & 1,03 & 0 \\
\hline 54 & Not ident. & 0,19 & 0 \\
\hline
\end{tabular}




\begin{tabular}{|c|l|c|c|}
\hline 56 & Bulnesene alpha & 2,65 & 0 \\
\hline 57 & Amorphene epsylon & 1,24 & 0,25 \\
\hline 58 & Cadinene delta & 1,15 & 0,47 \\
\hline 59 & Spathulenol & 0,43 & 0 \\
\hline & $\begin{array}{l}\text { 1H-Cycloprop[e]azulen- } \\
\text { 7-ol, decahydro-1,1,7- } \\
\text { trimethyl-4-methylene-, } \\
{[1 \text { ar- }} \\
\text { (1a.alpha.,4a.alpha.,7.beta } \\
\text {.7a.beta.,7b.alpha.)]- }\end{array}$ & 2,43 & \\
\hline 61 & Caryophyllene oxide & & \\
\hline 62 & Not ident. & 3,35 & 0,21 \\
\hline 63 & Not ident. & 0 & 0,69 \\
\hline 64 & Humulene epoxide II & 1,05 & 0,21 \\
\hline 65 & Not ident. & 0,59 & 0 \\
\hline 66 & Cadin-4-en-10-ol & 0,56 & 0,26 \\
\hline 67 & tetradecanal & 0 & 0,58 \\
\hline & $\begin{array}{l}\text { 6-Isopropenyl-4,8a- } \\
\text { dimethyl-1,2,3,5,6,7,8,8a- } \\
\text { octahydro-naphthalen-2- } \\
\text { ol }\end{array}$ & 0 & 0,21 \\
\hline 69 & Cadinol alpha & & \\
\hline 70 & Not ident. & 0,74 & 0 \\
\hline 71 & Not ident. & 0 & 1,20 \\
\hline 72 & Not ident. & 0,74 & 0 \\
\hline 73 & Chamazulene & & 0,17 \\
\hline
\end{tabular}

Source: Compiled by the authors.

As can be seen from the table, 51 compounds were found in the essential oil of the aerial part of the Charoda sample of A. vulgaris (4 of them were not identified), and 56 compounds were isolated in the Kurush sample of this species (4 of them were not identified).

\section{Discussion}

As the results show, the main compounds of the essential oil of the Dagestan samples of wormwood are pinene beta, sabinene, myrcene, eucalyptol, terpinene gamma, thujone beta, Verbenol trans, terpinen - 4 -ol, chrysanthenyl acetate - trans, Isogermacrene D, muurolene epsylon, Humulene alpha, Cadinene gamma, Selynene -beta, Bulnesene alpha, Amorphene epsilon, Cadinene delta,, 1H-Cycloprop[e]azulen-7-ol, decahydro-1,1,7trimethyl-4-methylene-, [1 [1ar-(1a.alpha.,4a.alpha.,7.beta.,7a.beta.,7b.alpha.)]-, Caryophyllene oxide, Humulene epoxide II, Chamazulene.

We considered the main compounds to be compounds with a content of more than $1 \%$. It should be noted that the component composition of essential oils of the two populations differs both in quality and in the content of components. Perhaps this is due to the abiotic factors of the environment in which the plants grew, since the harvesting phase was the same. A high percentage of chamazulene was found in the Charodinsky sample of essential oil, while in the sample collected at an altitude of over $2000 \mathrm{~m}$ above sea level, it was not found. Perhaps this is somehow related to the soil or other factors, as noted by the authors [25]. The oils obtained also differed in color.

The samples also differ in the content of the main component. So, in the enchanting sample, the main components are eucalyptoл $(3,68 \%)$, bicoclogermacrene $(5,75 \%)$, Cyclohexane,1-ethenyk-1-methyl-2,4-bis(1-methylethenyl)-, [1S-(1.alpha.,2.beta.,4.beta.)] 
$(4,29 \%)$, Caryophyllene trans $(8,69 \%)$, Cubebene beta $-(34,74 \%)$, Caryophyllene oxide $(3,35 \%)$, Chamazulene $(6,17 \%)$.

In the Kurush oil sample, the main ingredients are sabinene $(3,12 \%)$, myrcene $(2,61 \%)$, Thujone -beta (5,58\%), Verbenol trans (2,36\%), терпинен-4-ол $(2,38 \%)$, chrysanthenyl acetate - trans $(27,51 \%)$, Sabinyl-acetate trans $(9,23 \%)$, Cyclohexane,1-ethenyk-1-methyl2,4-bis(1-methylethenyl)-, [1S-(1.alpha.,2.beta.,4.beta.)] (4,02\%), Cadinene gamma $(6,90 \%)$, Selynene -beta $(4,78 \%)$.

As you can see, among the selected main compounds in two samples, one nonpenoidal compound is found - Cyclohexane, 1-ethenyk-1-methyl-2,4-bis (1-methylethenyl) -, [1S(1.alpha., 2.beta ., 4.beta.)], With almost the same content. It is also interesting to note that the studied two samples of essential oil are very different in some compounds. Thus, a sample of the essential oil of the aerial part of A. vulgaris collected in the vicinity of the village of Charoda contains the maximum amount of cubebene beta $(34.74 \%)$ versus $1.39 \%$ of this compound in a sample of essential oil from the Kurush population.

The maximum content of another valuable component - Chrysanthenyl acetate - trans is observed in a sample of wormwood essential oil from the Kurush population. Hence, each sample can be a source of certain essential oil components.

When comparing our results with some literature data on the component composition of essential oils of various A. vulgaris samples, we observe the following pattern (Table 2).

Table 2. Component composition of the essential oil of the aerial part of A.vulgaris L. according to some literature data.

\begin{tabular}{|c|c|c|}
\hline $\begin{array}{l}\text { № } \\
\text { II/II }\end{array}$ & Compound name and content, \% & $\begin{array}{l}\text { Sou } \\
\text { rces }\end{array}$ \\
\hline 1 & $\begin{array}{l}\text { Aerial part of A. vulgaris from nature: } 1,8 \text {-cineole }(46.50 \%) \text {, borneol }(10.17 \%) \text {, } \\
\text { piperitol }(9.52 \%), \alpha \text {-cadinene }(8.92 \%) \text {, camphor }(6,22 \%) \text {, humulene }(5.47 \%) \text { and } \\
1,4 \text {-cineole }(4.25 \%) \text {. } \\
\text { From the leaves of A. vulgaris grown in a greenhouse: camphor }(16.8 \%), \alpha \text {-thujone } \\
(11.3 \%) \text {, germacrene D }(7.2 \%) \text {, camphene }(6.5 \%), 1,8 \text {-cineole }(5.8 \%) \text { and } \beta \text { - } \\
\text { caryophyllene }(5.4 \%)\end{array}$ & {$[30]$} \\
\hline 2 & Aerial part of A. vulgaris: camphor (29.49\%) and borneol (14.71\%) & {$[29]$} \\
\hline \multirow{4}{*}{3} & $\begin{array}{l}\text { Aerial part of A. vulgaris: camphene (1.88); 1,8-cineole (2.13); camphor (38.05); } \\
\text { borneol (6.21); terpineol-4 (3.15; piperitone (1.68); bornyl acetate (1.43); longipinene } \\
\text { (1.53); caryophyllene (1.16); germacrene D (4.49) } \\
\beta \text {-selenene (2.09); presilferfolan-9- } \alpha \text {-ol (3.04); spatulenol (2.99); caryophyllene oxide } \\
\text { (5.47); } \beta \text {-panasinsen (4.81); hexadecanal (1.10) }\end{array}$ & [17] \\
\hline & $\begin{array}{l}\text { Aerial part of A. vulgaris: thujone ( } 60.28 \%) \text {, caryophyllene oxide }(11.46 \%), \alpha- \\
\text { thujone }(9.46 \%), 1.8 \text { cineole }(5.06 \%) \text {, trans-caryophyllene (3.57) and linalool } \\
(3.40 \%) \text {. }\end{array}$ & [16] \\
\hline & $\begin{array}{l}\text { Aerial part of A. vulgaris: artemisia ketone (6.77-29.38), trans-caryophyllene (6.22- } \\
6.94), 1,8 \text {-cineole (4.75-5.13), p-cymene (7.60), yomogi alcohol (5.48) }\end{array}$ & 26 \\
\hline & $\begin{array}{l}\text { Aerial part of A. vulgaris: davanones }(13.8-45.5, \text { six oils }) \text {, germacrene } \mathrm{D}(9.1-30.5 \text {, } \\
\text { four oils), } 1,8 \text {-cineole }(16.4 \text {, one oil }) \text {, camphor }(18.9 \text {, one oil), trans-thujone ( } 8.9 \text { and } \\
10.9 \text {, two oils), cis-chrysanthenyl acetate }(10.4, \text { one oil })\end{array}$ & 27 \\
\hline
\end{tabular}

Analysis of literature data shows that, regardless of the region, the main components of A. vulgaris essential oil are camphor, borneol, 1,8-cineole, spatulenol, their quantitative content in the essential oil varies. The composition of the A. vulgaris essential oil growing in Dagestan is somewhat different in terms of the qualitative and especially quantitative content of components from those of essential oils from other regions.

In the literature, the main compound of wormwood is usually camphor or 1.8 cineole, and in our samples, trans-crisanthenyl acetate (27.51\%), beta-cubeben (34.74\%). Borneol, 
which is found in the literature as the main component, is contained in a small amount in Dagestan populations: $0.39 \%$ versus $6.21 \%$ [17], 10.17\% [30], 14.71\% [29].

\section{Conclusion}

Thus, for the first time in the natural Dagestan flora (Russia), we obtained data on the release of essential oil and its component composition in the aerial part of A. vulgaris, collected at two geographical points during the flowering phase. The results obtained differ in the qualitative and quantitative content of the main components of essential oils of two Dagestan samples of A. vulgaris, and in comparison with the literature, which indicates a wide variety of factors affecting the variability of secondary products in medicinal plants.

The results obtained can contribute to the explanation of the regularities of the variability of the component composition, the accumulation of essential oil, depending on the place of collection of medicinal plants. In addition, our data allow us to recommend samples of A.vulgaris essential oils as sources of compounds valuable from the point of view of pharmacological and chemical activity.

\section{References}

1. A. K. Pandey, Pooja Singh., Medicines, 4, 1 (2017)

2. S. Cavar, M. Maksimovic, D. Vidic, A. Paric, Ind. Crop. Prod., 37, 479 (2012)

3. S. C. Sati, N. Sati, V. Ahluwalia, S. Walia, O. P. Sat, O.P. Nat, Prod. Res., 27, 45 (2013)

4. J. Al-Shuneigat, S. Al-Sarayreh, M. Al-Qudah, et al., Br. J. Med. Med. Res., 5, 297 (2015)

5. G. I. Kalinkina, T. P. Berezovskaya, S. E. Dmitruk, E. N. Salnikova, Chemistry of vegetable raw materials, 3, 5 (2000)

6. M. Maham, H. Moslemzadeh, G. Jalilzadeh-Amin, Pharm. Biol., 52, 208 (2014)

7. S. S. Chu, Z. L. Liu, S. S. Du, Z. W. Deng, Molecules, 17, 7255 (2012)

8. A. Judzentiene, J. Budiene, R. Gircyte, V. Masotti, I. Laffont-Schwob, I. Rec, Nat. Prod., 6, 180 (2012)

9. M. Kazemi, M. Dakhili, A. Dadkhah, M. Fadaeian, S. Shafizadeh, Asian J. Chem., 25, 47 (2013)

10. T. Mihajilov-Krstev, B. Jovanovic, J. Jovic, et al., Planta Med., 80, 1698 (2014)

11. H. A.E. Shaaban, A. H. El-Ghorab, T. Shibamoto, The Journal of Essential Oil Research, 24, 2 (2012)

12. V. A. Dubinskaya, N. A. Polyakov, A.A. Evremov, E. A. Evremov, Chemistry of vegetable raw materials, 149, 3 (2013)

13. A. M. Saleh, A. Aljada, S. A. A Rizvi, et al., BMC Complementary and Alternative Medicine, 14, 226 (2014)

14. B. Ivănescu, A. F. Burlec, F. Crivoi, C. Roșu, A. Corciovă, Molecules, 26, 10 (2021)

15. A. Capuzzo, A. Occhipinti, M.E. Maffei, Nat Prod Res., 28, 24 (2014)

16. B.Yildirim, A. M. Kumlay, K. Ekici, K. Afshar, Pour Rezaeieh, International Scientific Researches Journal «Ponte», 72, 9 (2016)

17. S. V. Zhigzhitzhapova, T. E. Soktoeva, L. D Radnaeva L.D., V. V.Taraskin, B.-Ts. B. Namzalov, 74 (2012) 
18. M. R. Naghavi, F. Alaeimoghadam, H. Ghafoori, International Journal of Biological, 8, 11 (2014)

19. H. Ekiert, J. Pajor, P. Klin, et al., Molecules 25, 19 (2020)

20. C. Denys, H. Schmidt, Oecologia, 113 (1998)

21. J. Wanga, F. Zhua, X. M. Zhoua, et al., Journal of Stored Products Research, 42 (2006)

22. S. Govindaraj, B. D RanjithaKumari, P. L. Cioni, G. Flamini, Journal of Bioscience and Bioengineering, 105, 3 (2008)

23. L. N. Misra, S. P. Singh, Journal Natural Products, 49, 5 (1986)

24. P. D. Haider, A. A. Dwivedi, A. A. Naqvi, G.D. Bagchi, Journal of Essential Oil Research,15, 6 (2003)

25. I. R. Danileiko, N. N. Apykhtin, V. V. Plemenkov, Bulletin of the Baltic Federal University. I. Kant, 7, 33 (2012)

26. H. Lohani, G. Gwari, U. Bhandari, S. Z. Haider, H. Andola, N. Chauhan, Plants, 19, 103 (2016)

27. A. Judzentiene, J. Buzelyte, Chemija, 17, 1 (2006)

28. W. A. König, I. Jerkovic, J. Mastelic, M. Milos, F. Juteau, V. Masotti, J. Viano, Flavour and Fragrance Journal, 18, 5 (2003)

29. A. A. Alyakin, A. A. Evremov, A. S. Angaskieva, V. V. Grebennikova, Chemistry of vegetable raw materials, 3, 123 (2011)

30. N. I. Grinkevich, L. N. Safronovich, Chemical analysis of medicinal plants, 176 (1983)

31. J. D. Williams, M. A. Campbell, M. C. Jaskolka, T. Xie, American Journal of Plant Sciences, 4, 1265 (2013)

32. R. A. Murtazaliev, Abstract of the flora of Dagestan, 3, 43 (2009)

33. State Pharmacopoeia, 1, 2 (1998)

34. A.M. Aliev, G.K. Radjabov, A.M. Musaev, The Journal of Supercritical Fluids, 102, $66(2015)$

35. A. V. Tkachev, Study of plant volatiles, 969 (2008) 